\title{
MANAGEMENT OF Bidens pilosa AND Commelina benghalensis IN ORganic Corn Cultivation Under No-Tillage ${ }^{1}$
}

\author{
Manejo de Bidens pilosa e Commelina benghalensis no Cultivo de Milho Orgânico em Sistema \\ de Plantio Direto
}

\author{
LEMOS, J.P. ${ }^{2}$, GALVÃO, J.C.C. ${ }^{3}$, SILVA, A.A. ${ }^{4}$, FONTANETTI, A. ${ }^{5}$, CECON, P.R. ${ }^{6}$, and \\ LEMOS, L.M.C. ${ }^{7}$
}

\begin{abstract}
Mowing is one of the most important methods used to control weeds in organic farming, under the no-tillage system. This study aimed to evaluate the effects of three weed management techniques on weed development, using the weeds Bidens pilosa and Commelina benghalensis, in competition with organic corn \{mowing at the three-leaf stage (14 days after corn emergence - DACE), mowing at the three- and six-leaf stage (14 and $25 \mathrm{DACE})$, and no mowing. Single cultivation with no mowing was also evaluated for these weeds. Mowings performed at 14 and 25 DACE prevented the production of $B$. pilosa seeds, ensuring efficient control of this species. However, the use of this technique was shown to be inefficient in the control of $C$. benghalensis.
\end{abstract}

Keywords: mowings, regrowth, morphology, competition.

\begin{abstract}
RESUMO - A roçada é um dos métodos de maior importância no controle de plantas daninhas, em cultivos orgânicos, no sistema de plantio direto. Neste trabalho foram avaliados os efeitos de três manejos de plantas de Bidens pilosa e Commelina benghalensis, em competição com o milho \{roçadas no estádio de três folhas do milho (14 dias após emergência do milho-DAEM), roçadas no estádio de três e seis folhas do milho (14 e 25 DAEM) e não roçadas\}, sobre o desenvolvimento das plantas daninhas. Foi avaliado também o cultivo solteiro dessas plantas daninhas sem o uso de roçadas. Roçadas realizadas aos 14 e 25 DAEMimpediram a produção de sementes de B. pilosa, garantindo eficiente controle dessa espécie. Todavia, o uso dessa técnica mostrou-se ineficiente para o controle de C. benghalensis.
\end{abstract}

Palavras-chave: roçadas, rebrota, morfologia, competição.

\section{INTRODUCTION}

The organic cultivation of corn under the no-tillage system is a viable soil management option because it allows for increased organic matter, among other benefits. However, corn is sensitive to competition with weeds especially in the first four weeks after planting (Olorunmaiye \& Olorunmaiye, 2009), which makes corn production unfeasible under a no-tillage system because weed infestation can reach high levels after three or four years of cultivation (Corrêa et al., 2011).

1 Recebido para publicação em 3.9.2012 e aprovado em 26.12.2012.

Parte da Dissertação de Mestrado do primeiro autor, apresentada ao Programa de Pós-Graduação em Fitotecnia da Universidade Federal de Viçosa - UFV.

2 Engo-Agr ${ }^{0}$., M.Sc., Estudante de Doutorado, Dep. de Fitotecnia, Universidade Federal de Viçosa - DFT/UFV, Avenida Peter Henry Rolfs, s/n, Campus Universitário, 36570-000 Viçosa-MG, Bolsista CNPq, <agrolemos@hotmail.com>; ${ }^{3}$ Eng - -Agr ${ }^{\circ}$., D.Sc., Professor, DFT/UFV, Bolsista do CNPq, <jgalvao@ufv.br>; ${ }^{4}$ Engo-Agro ${ }^{\circ}$., D.Sc., Professor, DFT/UFV, Bolsista do CNPq, <aasilva@ufv.br>; ${ }^{5}$ Eng ${ }^{\underline{a}-A g r}{ }^{\mathrm{a}}$., D.Sc., Professora, Dep. de Agronomia, Centro de Ciências Agrárias, Universidade Federal de São Carlos - UFSCAR, Rod. Anhanguera, Km 174, Caixa Postal 330, 13600-970 Araras-SP, Brasil, <afontanetti@yahoo.com.br>;

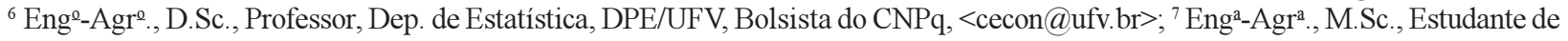
Doutorado, DFT/UFV, 36570-000 Viçosa-MG, Bolsista CNPq, <lorenamcarvalho@yahoo.com.br>. 
Bidens pilosa and Commelina benghalensis are among the most important weed species in Brazilian corn crops (Vaz de Melo et al., 2007; Chiovato et al., 2007, Pereira et al., 2009; Queiroz et al., 2010; Corrêa et al., 2011). Because of their high capacity for regrowth and vegetative reproduction, these weed species are considered to be difficult to manage mechanically, particularly when their control is accomplished by mowing. Mowing efficiency depends largely on the particular weed species, their frequency in the area, the stage of plant development, the rate of soil covered by the crop (Queiroz et al., 2010) and the time when mowing is performed (Kozlowski et al., 2009). The percentage of leaf loss resulting from mowing represents a decrease in light interception, as well as lower rates of canopy net photosynthesis. However, in some cases there is an offsetting effect from the occurrence of plant stress (Zagonel et al., 2000), which will result in weed recovery in the field, and a possible reduction in crop yield potential.

Given the above, this study evaluated the effect of mowing Bidens pilosa and Commelina benghalensis plants at different times, whether or not grown in competition with corn, on the development of such weeds.

\section{MATERIAL AND METHODS}

The study was conducted in a greenhouse in a randomized complete block design with three replications in a factorial $2 \times 3+2$ arrangement. The first factor was composed of two weed species (Bidens pilosa and Commelina benghalensis); the second, of three techniques for the management of these plants \{mowings at the three-leaf stage of corn (14 days after corn emergence - DACE), mowing at the three-leaf and six-leaf stage of corn (14 and 25 DACE) and no mowing\}. The additional treatments (controls) consisted of monocrops of B. pilosa and $C$. benghalensis with no mowing.

The corn variety cultivated was UFVM 100 , originated from open pollination. Corn was sown six days after $C$. benghalensis and two days after $B$. pilosa, aiming at the simultaneous emergence of corn and weeds. The experimental plot consisted of a pot with the following dimensions: $35 \mathrm{~cm}$ top diameter, $22 \mathrm{~cm}$ bottom diameter and $34 \mathrm{~cm}$ in height, containing $24.2 \mathrm{~kg}$ of the substrate with a density of $1.1 \mathrm{~g} \mathrm{~cm}^{-3}$. The substrate used was a mixture of soil collected at a cliff $\{$ Oxisol with a loam texture $(52 \%$ sand, $10 \%$ silt and $38 \%$ clay)\}, with organic compost and thermomagnesium phosphate. Table 1 shows the chemical properties of the soil. The results of the chemical analysis of the compost used were: $16.6 \mathrm{~g} \mathrm{~kg}^{-1}$ total $\mathrm{N}$; $4.19 \mathrm{~g} \mathrm{~kg}^{-1} \mathrm{P}$; $2.62 \mathrm{~g} \mathrm{~kg}^{-1} \mathrm{~K} ; 9.56 \mathrm{~g} \mathrm{~kg}^{-1} \mathrm{Ca} ; 3.68 \mathrm{~g} \mathrm{~kg}^{-1} \mathrm{Mg}$; $2.11 \mathrm{~g} \mathrm{~kg}^{-1} \mathrm{~S} ; 10.75 \mathrm{mg} \mathrm{kg}^{-1} \mathrm{~B} ; 35.62 \mathrm{Mg} \mathrm{kg}^{-1} \mathrm{Cu}$; $214.73 \mathrm{mg} \mathrm{kg}^{-1} \mathrm{Mn}$, and $71.8 \mathrm{mg} \mathrm{kg}^{-1} \mathrm{Zn}$ based on dry weight.

Before the pots were filled, the soil was air dried, crumbled and sieved through a $20 \mathrm{~mm}$ mesh. The substrate was composed of $1.85 \%$ organic compost, $0.15 \% \mathrm{P}_{2} \mathrm{O}_{5}$ as thermo-magnesium phosphate and soil, as recommended by Chiovato et al. (2007). Subsequently, ten weed seeds and two corn seeds were planted in each pot, and then covered with $3 \mathrm{~cm}$ of substrate. Thinning was performed at five days after the emergence of the plants. Six weeds and a corn plant were left in each pot, i.e., according to the treatments established in each pot, a corn plant was planted in competition with six B. pilosa or C. benghalensis plants. The same procedure was performed for the weed monocrops.

Table 1 - Results of chemical analyzes of the Oxisol used in the experiment. Viçosa-MG, 2010

\begin{tabular}{|c|c|c|c|c|c|c|c|c|c|c|}
\hline \multirow{2}{*}{$\mathrm{pH}$} & $\mathrm{P}$ & $\mathrm{K}$ & $\mathrm{Ca}$ & $\mathrm{Mg}$ & $\mathrm{Al}$ & $\mathrm{H}+\mathrm{AL}$ & $\mathrm{SB}$ & $\mathrm{CTC}(\mathrm{t})$ & $\mathrm{CTC}(\mathrm{T})$ & $\mathrm{V}$ \\
\cline { 2 - 12 } & \multicolumn{2}{|c|}{$\left(\mathrm{mg} \mathrm{dm}^{-3}\right)$} & \multicolumn{8}{|c|}{$\left(\mathrm{cmol}_{\mathrm{c}} \mathrm{dm}^{-3}\right)$} \\
\hline 5.4 & 1.7 & 73 & 3.3 & 1.1 & 0 & 3.63 & 4.59 & 4.59 & 8.22 & 56 \\
\hline
\end{tabular}

The chemical composition was determined as specified by Embrapa (1997); $\mathrm{pH}$ in water at a ratio of 1: 2.5 for soil: water, $\mathrm{Ca}, \mathrm{Mg}$ and $\mathrm{Al}$ = extractor $\mathrm{KCl} 1 \mathrm{~N} ; \mathrm{P}$ and $\mathrm{K}$ = extractor Mehlich-1; extractable acidity $\mathrm{H}+\mathrm{Al}$ = extractor SMP. SB - Soma de bases; CTC (t) - Capacidade de troca de cátions efetiva; CTC $(\mathrm{T})$ - Capacidade de troca de cátions a $\mathrm{pH}$ 7,0 e V - Saturação por bases. 
During the experiment, daily drip irrigation was used for the pots in order to keep humidity around $80 \%$ of field capacity. In the greenhouse, preliminary tests were performed for plant emergence to determine the time required for the emergence of each species and, thus, plant them to obtain simultaneous emergence. The period of interference between the corn plant and the weeds was 58 days, i.e., from plant emergence to the bloom of the corn plants.

The weeds were weeded with a pair of stainless steel scissors ( 4 to $5 \mathrm{~cm}$ from the soil surface) at two times: first when the corn plants had three fully expanded leaves (at 15 DACE), and then when the corn plants had six fully expanded leaves (to 25 DACE).

The morphological properties of corn evaluated at full bloom (58 DACE) were: total number of leaves, counted manually; stem diameter, measured with a caliper at $4 \mathrm{~cm}$ from the soil surface in whole and regrown plants; height of B. pilosa plants, measured with a ruler, and stem length of $C$. benghalensis plants, measured with a tape measure. In the case of treatments with mowings when there was regrowth of the plants of $C$. benghalensis, values for height and diameter were obtained of the same plants that had been weeded, differentiated by a string tied on the stem.

The dry weight of the weed seeds of $B$. pilosa and $C$. benghalensis was evaluated. The seeds were collected from the moment the weed seeds were released until corn was at full bloom.

To determine leaf dry weight (LDW), stem dry weight (SDW), root dry weight (RDW) and seed dry weight (SeDW), the plants were separated into leaves, seeds, stems and roots, placed in paper bags, and taken to a forced air circulation oven at $70^{\circ} \mathrm{C}$ until they reached a constant weight.

Through the analysis of growth, the following physiological indices were measured for the weeds: specific leaf area (SLA), in $\mathrm{cm}^{2} \mathrm{~g}^{-1}$; ratio of the area of the youngest fully expanded leaf \{examined in a LI-COR (LI-3000) leaf area meter and the dry weight of the same leaf; leaf mass ratio (LMR), in $\mathrm{g} \mathrm{g}^{-1}$, obtained from the dry weight of the leaves and the total dry weight; stem mass ratio (SMR) in $\mathrm{g} \mathrm{g}^{-1}$, obtained from the stem dry weight and the total dry weight; root mass ratio (RMR) in $\mathrm{g} \mathrm{g}^{-1}$, obtained from the root dry weight and the total dry weight; shoot/root ratio (S/R) in $\mathrm{g} \mathrm{g}^{-1}$, obtained from the sum of the dry weight of the shoot of the plant (leaf + stem) divided by the root dry weight.

The results of these measurements were submitted to analysis of variance and the means were compared by the Tukey's and Dunnet tests at 5\% significance.

\section{RESULTS AND DISCUSSION}

Significant interaction could be identified between the weed species and mowing management for the following properties: seed dry weight (SDW), stem mass ratio (SMR), seed mass ratio (SeMR), plant height $(\mathrm{PH})$, stem diameter (DIAM), total number of leaves (TNL) and specific leaf area (SLA). Thus, the interaction among these properties was unfolded, focusing on the forms of management for each weed species.

Table 2 shows that the coexistence with corn did not alter the properties measured for B. pilosa plants. However, competition affected the development of the species C. benghalensis, mainly on plant height $(\mathrm{PH})$, root dry weight (RDW) and seed dry weight (SDW).

Competition against a culture is one of the most effective tools in reducing weed growth, and it plays a crucial role in integrated management programs of these plants (Kozlowski et al., 2009). It is likely that the corn plants and $C$. benghalensis required similar amounts of water and nutrients when in competition. However, because corn has a $\mathrm{C} 4$ photosynthetic pathway and an erect growth habit, corn plants become more efficient in the use and competition for light when compared with $C$. benghalensis (C3). Therefore, the efficient use of resources by the culture may have favored the reduction in weed competition.

It is observed that the control treatments (B. pilosa and C. benghalensis monocrops) differed from the treatments with two mowings (Corn and $\mathrm{B} / 2 \mathrm{w}$, and Corn and $\mathrm{C} / 2 \mathrm{r}$ ). There was an effect on the species $B$. pilosa on for 
Table 2 - Mean values of plant height (PH), stem diameter (DIAM), leaf dry weight (LDW), stem dry weight (SDW), root dry weight (RDW), seed dry weight (SeDW), stem mass ratio (SMR), seed mass ratio (SMR), total number of leaves (TNL), specific leaf area of the leaf (SLA) and ratio shoot/root system (S/R) and of Bidens pilosa and Commelina benghalensis. Viçosa-MG, 2010

\begin{tabular}{|c|c|c|c|c|c|c|c|c|c|c|c|}
\hline \multirow{2}{*}{ Treatment } & $\mathrm{PH}$ & DIAM & LDW & SDW & RDW & SeDW & SMR & SeMR & \multirow{2}{*}{ TNL } & \multirow{2}{*}{$\frac{\text { SLA }}{\left(\mathrm{cm}^{2} \mathrm{~g}^{-1}\right)}$} & \multirow{2}{*}{$\frac{\mathrm{S} / \mathrm{R}}{\left(\mathrm{g} \mathrm{g}^{-1}\right)}$} \\
\hline & \multicolumn{2}{|c|}{$(\mathrm{cm})$} & \multicolumn{4}{|c|}{$(\mathrm{g})$} & \multicolumn{2}{|c|}{$\left(\mathrm{g} \mathrm{g}^{-1}\right)$} & & & \\
\hline B. pilosa monoc. $\mathrm{nw}$ & 111.66 & 0.73 & 17.98 & 34.34 & - & 10.04 & 0.47 & 0.14 & - & 336.69 & $21.75^{*}$ \\
\hline B. pilosa + corn nw & 116.33 & 0.72 & 19.41 & 45.77 & - & 10.69 & 0.52 & 0.12 & - & 312.09 & 26.53 \\
\hline B. pilosa + corn $1 \mathrm{w}$ & $50.52 *$ & $0.36^{*}$ & $7.26^{*}$ & $11.25^{*}$ & - & $2.04 *$ & 0.42 & $0.07 *$ & - & 534.03* & 9.46 \\
\hline B. pilos $a+\operatorname{corn} 2 \mathrm{w}$ & $4.56^{*}$ & $0.12 *$ & $0.15^{*}$ & $0.11 *$ & - & $0.00^{*}$ & $0.16^{*}$ & $0.00^{*}$ & - & 223.29 & $0.61 *$ \\
\hline C. benghalensis monoc. nw & 64.22 & 0.46 & 18.26 & - & 22.10 & 13.20 & - & - & 149 & - & 22.11 \\
\hline C. benghalensis + corn nw & $50.91 *$ & 0.46 & 17.53 & - & $6.18^{*}$ & $7.72 *$ & - & - & 136 & - & 25.51 \\
\hline C. benghalensis + corn $1 \mathrm{w}$ & $34.05 *$ & $0.34 *$ & $7.11^{*}$ & - & $3.67 *$ & $1.50^{*}$ & - & - & $54 *$ & - & $10.51^{*}$ \\
\hline C. benghalensis $+\operatorname{corn} 2 \mathrm{w}$ & $16.90^{*}$ & $0.33^{*}$ & $4.12^{*}$ & - & $3.19^{*}$ & $1.15^{*}$ & - & - & $36^{*}$ & - & $7.24 *$ \\
\hline
\end{tabular}

* Means that differ from the control at $5 \%$ probability by the Dunnett test.

B. pilosa monoc. nw - Bidens pilosa monocrop/with no mowing; B. pilosa + corn nw- Bidens pilosa and corn/with no mowing; B. pilosa + corn $1 \mathrm{w}-$ Bidens pilosa and corn/one mowing; B. pilosa corn $+2 \mathrm{r}-$ Bidens pilosa and corn/two mowings; 2nd part - C. benghalensis monoc. nw - monocrop of Commelina benghalensis/with no mowing; C. benghalensis + corn nw - C. benghalensis + corn/ with no mowing; C. benghalensis + corn $1 \mathrm{w}-$ Commelina benghalensis and corn/one mowing, and C. benghalensis + corn $2 \mathrm{w}-$ Commelina benghalensis and corn / two mowings.

the properties PH, DIAM, LDW, SDW, RDW, SeDW, SMR, SeMR and S/R, except for specific leaf area (SLA). However, there was a significant effect on $C$. benghalensis for $\mathrm{PH}$, DIAM, RDW, SeDW, TNL and S/R, except for leaf dry weight (LDW).

It can be stated that the use of two mowings was effective in controlling weeds and that, generally, the development of these species was impaired (PH, DIAM, RDW, SeDW and S/R), i.e., the competition against the corn plants for resources was reduced. The severe reduction in the reserves of these weeds decreases their likelihood of resuming growth and causing significant damage to the development of corn plants (Olorunmaiye \& Olorunmaiye, 2009).

As the interaction between weed species and the management techniques was unfolded, it was found that the treatment with two mowings $(2 \mathrm{~W})$ had lower average plant height in relation to others, and it was considered the best result in the growth control of these plants, especially B. pilosa (Table 3). There was a decrease of $96.07 \%$ in the plant height of $B$. pilosa comparing the treatment with no mowing and $2 \mathrm{~W}$. The average height of $B$. pilosa was greater than that of $C$. benghalensis in treatments with one mowing and with no mowing, but $B$. pilosa was the most affected species when two mowings were used; it had low recovery at the end of the corn cycle, compared to $C$. benghalensis.

The morphophysiological behavior of corn in competition against different weeds may foster the understanding of the competitive potential of these species. Accordingly, Lemos et al. (2012) found that, with no mowing, $B$. pilosa showed greater capacity to interfere in the morphological behavior of corn, reducing the leaf mass ratio and increasing the root mass ratio. However, $C$. benghalensis showed greater capacity to interfere in the accumulation of the total dry weight of corn. It is likely that the growth habit of these plants and the intrinsic nutritional needs of each species may result in different forms of competition (Rocha et al. 2007) and recovery after management by mowing. The species $C$. benghalensis, because of its greater potential on carbon consumption, increased water-use efficiency (Aspiazu et al. 2010) and has a clearly greater number of branches of the stem formed at the base of the plant compared to B. pilosa. This may have favored the recovery of the former after the second mowing.

For the different management techniques used, there was variation in the diameter of the plants (DIAM), with lower average for the two mowings. In the treatment with two mowings, the species $C$. benghalensis had 
greater diameter than B. pilosa, but the opposite result was observed in the treatment with no mowing. Similar results were found by Kozlowski et al. (2009), who confirmed the superiority of taller weeds, developed at the more advanced stages of corn development, whereas the lower weeds were removed or died. The differences in height of crops and weeds can be partly considered as an interaction during the competition for light. Elongation may occur to increase plant height induced by competition of light (Karimmojeni et al., 2010).

It was observed that $C$. benghalensis plants were more efficient in shoot recovery compared to $B$. pilosa, especially with regard to the resumption of growth and development of the shoot after the second mowing. However, the total number of leaves of $B$. pilosa plants did not differ across treatments that used mowing or not. Similar results were obtained by Vaz de Melo et al. (2007), who found high regrowth capacity of $B$. pilosa plants.

There was no difference between the species in the number of total leaves, considering the different management techniques used. Interestingly, $C$. benghalensis produced 3.1 times more leaves than B. pilosa, both without mowing interference. This different behavior is due to the intrinsic properties of each species, because they are totally different in terms of their development and ability to survive in harsh environmental conditions.

In the combined analysis of the properties $\mathrm{PH}$, DIAM and NL in the treatments $1 \mathrm{~W}$ and $\mathrm{NW}$, it is observed that the $\mathrm{PH}$ and $\mathrm{NL}$ of $C$. benghalensis plants changed, but the diameter remained unreduced. After cutting, priority is likely to have shifted from leaf formation to the accumulation of reserves in the stem and propagating structures, which are located below ground surface (Gonzalez \& Haddad, 1995).

The B. pilosa plants that were weeded only once had higher specific leaf area (SLA), compared with the other management techniques. However, when these plants were subjected to two mowings, their SLA did not differ from that of the plants with no mowing (Table 4). The use of two mowings on plants of $B$. pilosa caused a reduction of

Table 3 - Mean values †of plant height (PH), stem diameter (DIAM) and total number of leaves (TNL) of weeds Bidens pilosa and Commelina benghalensis in different types of mowing management (NW - no mowing; $1 \mathrm{~W}$ - mowing at the three-leaf stage of corn, and 2W - mowing at the three- and six-leaf stages of corn) in the cultivation of corn. Viçosa-MG, 2010

\begin{tabular}{|c|c|c|c|c|c|c|}
\hline \multirow{2}{*}{ Management } & \multicolumn{2}{|c|}{ PH $(\mathrm{cm})$} & \multicolumn{2}{c|}{ DIAM $(\mathrm{cm})$} & \multicolumn{2}{c|}{ NL } \\
\cline { 2 - 7 } & B. pilosa & C. benghalensis & B. pilosa & C. benghalensis & B. pilosa & C. benghalensis \\
\hline SR & $116.33 \mathrm{aA}$ & $50.91 \mathrm{bA}$ & $0.72 \mathrm{aA}$ & $0.47 \mathrm{bA}$ & $44.00 \mathrm{bA}$ & $136.33 \mathrm{aA}$ \\
\hline 1R & $50.53 \mathrm{aB}$ & $34.06 \mathrm{bB}$ & $0.37 \mathrm{aB}$ & $0.35 \mathrm{aAB}$ & $35.67 \mathrm{aA}$ & $54.00 \mathrm{aB}$ \\
\hline 2R & $4.57 \mathrm{bC}$ & $16.90 \mathrm{aC}$ & $0.12 \mathrm{bC}$ & $0.33 \mathrm{aB}$ & $9.33 \mathrm{aA}$ & $36.67 \mathrm{aB}$ \\
\hline
\end{tabular}

Means followed by the same letters, uppercase and lowercase letters in columns in rows, for each variable, do not differ at $5 \%$ probability by the Tukey's test.

Table 4 - Mean values $\dagger$ of specific leaf area (SLA) and seed dry weight (SeDW) of weeds Bidens pilosa and Commelina benghalensis in different types of mowing management (NW - no mowing; $1 \mathrm{~W}$ - mowing at the three-leaf stage of corn, and 2W - mowing at the three- and six-leaf stages of corn) in the cultivation of corn. Viçosa-MG, 2010

\begin{tabular}{|c|c|c|c|c|}
\hline \multirow{2}{*}{ Management } & \multicolumn{2}{|c|}{ SLA $\left(\mathrm{cm}^{2} \mathrm{~g}^{-1}\right)$} & \multicolumn{2}{c|}{ SeDW $(\mathrm{g})$} \\
\cline { 2 - 5 } & B. pilosa & C. benghalensis & B. pilosa & C. benghalensis \\
\hline SR & $312.10 \mathrm{aB}$ & $345.24 \mathrm{aA}$ & $10.39 \mathrm{aA}$ & $7.73 \mathrm{bA}$ \\
\hline 1R & $534.03 \mathrm{aA}$ & $314.10 \mathrm{bA}$ & $2.04 \mathrm{aB}$ & $1.50 \mathrm{aB}$ \\
\hline 2R & $223.29 \mathrm{aB}$ & $383.38 \mathrm{aA}$ & $0.00 \mathrm{aC}$ & $1.15 \mathrm{aB}$ \\
\hline
\end{tabular}

Means followed by same letters, uppercase and lowercase letters in columns in rows, for each variable, do not differ at $5 \%$ probability by the Tukey's test. 
$58.19 \%$ in comparison to the SLA of plants that were weeded once, which possibly makes them less competitive morphologically and physiologically. The morphological and physiological responses of plants to shade are basically the elongation of internodes, increased leaf area and plant height, leaf reorientation in favor of better light gathering, changes in the concentrations of chlorophyll and photosynthesis, among others (Rajcan et al. 2004). Comparing B. pilosa and $C$. benghalensis, it was observed that the SLA of the former was greater than the one of the latter in the treatment in which plants were weeded only once, and there were no differences in the other management techniques. With respect to this result, it appears that the greater the ripeness of leaf tissues, possibly the smaller the specific leaf area. Rodrigues et al. (2006), when evaluating the physiological properties of Cynodon sp. plants, found that the values of the fraction of biomass allocated to the leaves have a direct influence on the regrowth age of plants.

For stem mass ratio (SMR) and seed mass ratio (SeMR), the $1 \mathrm{~W}$ and $\mathrm{NW}$ treatments had equal and higher values than treatment $2 \mathrm{~W}$ in both features (SMR and SeMR). In the management with two mowings, $C$. benghalensis had greater values than B. pilosa for these properties (Table 4).

As for the average seed production of $B$. pilosa with different management techniques, the NW treatment was superior to the others. The use of only one mowing for B. pilosa plants reduced $80.37 \%$ of the seeds produced. However, plants that were weeded once produced more seeds as compared to those that were weeded twice. Even though these plants have a high regrowth capacity (Chiovato et al., 2007; Vaz de Melo et al., 2007; Corrêa et al., 2011), it can be stated that using two mowings provided the best way to control the spread of the seeds of this species, to the extent that the treatment does not produce seeds, and it is likely that the season and the interval between the mowings have been key factors in this context. The initial control of the weed community is important to reduce the potential and the ability of weed species to accumulate dry matter and mobilize resources from the environment and, therefore, their power of competitive interference on corn (Kozlowski et al. 2009).

Conclui-se que o uso de roçadas pode ser um método eficiente para controle de plantas daninhas na cultura do milho orgânico cultivado no sistema de plantio direto. Todavia, a eficiência desse método é dependente da espécie daninha a ser controlada. Roçadas realizadas aos 14 e 25 DAE impediram a produção de sementes de $B$. pilosa, garantindo eficiente controle dessa espécie. No entanto, o uso de roçadas mostrou-se ineficiente para o controle de $C$. benghalensis. It can be concluded that the use of mowings can be an effective method for weed control in organic corn grown under a no-tillage system. However, the efficiency of this method depends on the weed species to be controlled. Mowings performed at 14 and $25 \mathrm{DAE}$ prevented the production of $B$. pilosa seeds, ensuring efficient control of this species. However, the use of mowings proved ineffective for the control of $C$. benghalensis.

\section{ACKNOWLEDGEMENTS}

The authors would like to thank CNPq (National Council for Scientific and Technological Development) for the financial support to the project and the scholarships granted.

\section{LITERATURE CITED}

ASPIAZÚ, I. et al. Eficiéncia fotosintética y de uso del agua por malezas. Planta Daninha, v. 28, n. 1, p. 87-92, 2010.

CORRÊA, M. L. P. et al. Dinâmica populacional de plantas daninhas na cultura do milho em função de adubação e manejo Ci. Agron., v. 42, n. 2, p. 354-363, 2011

CHIOVATO, M. G. et al. Diferentes densidades de plantas daninhas e métodos de controle nos componentes de produção do milho orgânico. Planta Daninha, v. 25, n. 2, p. 277-283, 2007.

GONZALEZ, C. B.; HADDAD, C. R. B. Efeito da luz e temperatura na floração e germinação de sementes de Commelina benghalensis L. Braz. Arch. Biol. Technol., v. 38 , n. 2, p. $651-659,1995$

KARIMMOJENI, H. et al. Competitive interaction between maize, Xanthium strumarium and Datura stramonium affecting some canopy characteristics. Austr. J. Crop Sci., v. 4, n. 9 , p. $684-691,2010$ 
KOZLOWSKI, L. A.; KOEHLER, H. S.; PITELLI, R. A. Épocas e extensões do período de convivência das plantas daninhas interferindo na produtividade da cultura do milho (Zea mays). Planta Daninha, v. 27, n. 3, p. 481-490, 2009

LEMOS, J. P. et al. Morfofisiologia de plantas de milho em competição com picão-preto e trapoeraba submetidas a roçada. Planta Daninha, v. 30, n. 3, p. 487-496, 2012.

OLORUNMAIYE, P. M.; OLORUNMAIYE, K. S. Effect of integrated weed management on weed control and yield components of maize and cassava intercrop in a southern Guinea savanna ecology of Nigeria. Austr. J. Crop Sci., v. 3, n. 3, p. 129-136, 2009.

PEREIRA, L. C. et al. Competitividade do milho com plantas espontâneas em sistema de plantio direto orgânico. R. Bras. Agroecol., v. 4, n. 2, p. 4204-4207, 2009.

QUEIROZ, L. R. et al. Supressão de plantas daninhas e produção de milho verde orgânico em sistema de plantio direto. Planta Daninha, v. 28, n. 2, p. 263-270, 2010.
RAJCAN, I.; CHANDLERK, S.; WANTON, C. J. Red-farred ratio of reflected light: a hypothesis of why early-season weed control is important in corn. Weed Sci., v. 52, p. 774-778, 2004.

ROCHA, D. C.; RODELLA, R. A.; MARTINS, D. Caracterização morfológica de espécies de trapoeraba (Commelina spp.) utilizando a análise multivariada. Planta Daninha, v. 25, n. 4, p. 671-678, 2007.

RODRIGUES, L. R. A. et al. Avaliação de características fisiológicas de cinco cultivares de Cynodon. Acta Sci. An. Sci., v. 28 , n. 3, p. 245-250, 2006

VAZ DE MELO, A. et al. Dinâmica populacional de plantas daninhas em cultivo de milho-verde nos sistemas orgânico e tradicional. Planta Daninha, v. 25, n. 3, p. $521-527,2007$.

ZAGONEL, J.; VENÂNCIO, W. S.; KUNZ, R. P. Efeitos de métodos e épocas de controle das plantas daninhas na cultura do milho. Planta Daninha, v. 18, n. 1, p. 143-150, 2000. 